\title{
PEMBERIAN VITAMIN SEBAGAI PENANGANAN GANGGUAN REPRODUKSI SAPI KELOMPOK TERNAK DESA BABAKAN, KECAMATAN KARANGPLOSO, KABUPATEN MALANG
}

\author{
Vitamin Injection as Cow Reproduction Disorder Treatment for Babakan \\ Village Farmer Group in Karangploso Sub-District, Malang Regency \\ Viski Fitri Hendrawan ${ }^{1)}$, Aulia Firmawati ${ }^{1)}$, Desi Wulansari ${ }^{1)}$, Yudit Oktanella ${ }^{1)}$, Galuh Chandra Agustina ${ }^{1)}$ \\ ${ }^{1)}$ Fakultas Kedokteran Hewan Universitas Brawijaya, Jl. Puncak Dieng, Kunci, Kalisongo, Dau, Malang, Jawa \\ Timur 65151 \\ Email : viski_hendrawan88@yahoo.com
}

\begin{abstract}
ABSTRAK
Sapi merupakan ternak ruminansia yang sangat potensial di Indonesia. Setiap induk ternak mempunyai tiga kemungkinan status reproduksi yaitu: berada pada kondisi kesuburan yang normal, kondisi kemajiran yang ringan atau infertil, kondisi kemajiran yang tetap atau steril. Infertilitas adalah keadaan dimana derajat kesuburan ternak menurun yang disebabkan oleh adanya gangguan organ reproduksi. Infertil sifatnya sementara dan masih dapat diobati dan bila pengobatan berhasil maka masih dapat bereproduksi kembali. Kemajiran dengan derajat yang berat sifatnya permanen atau steril yaitu berhentinya proses reproduksi secara penuh dan tidak dapat diobati. Banyak faktor yang dapat menyebabkan kemajiran pada ternak khususnya sapi, yang mayoritas merupakan gangguan hormonal terutama hormon reproduksi yang menimbulkan gejala seperti silent heat (birahi tenang) dan subestrus (birahi pendek) disebabkan oleh rendahnya kadar hormon estrogen. Sedangkan untuk kasus delayed ovulasi (ovulasi tertunda), anovulasi (kegagalan ovulasi) dan kista folikuler disebabkan oleh rendahnya kadar hormon gonadotropin (FSH dan LH). Gangguan hormonal tersebut dapat terjadi pada indukan sapi perah berproduksi susu tinggi serta akibat adanya endometritis yang berasal dari kelahiran yang tidak normal, seperti: abortus, retensi sekundinarum, kelahiran premature, kelahiran kembar, distokia, ataupun perlukaan saat melakukan pertolongan kelahiran. Tujuan dari kegiatan ini adalah untuk menanggulangi gangguan reproduksi sapi serta dapat memperbaiki performa reproduksi sapi dengan melihat peningkatan angka kejadian birahi pada kelompok ternak di Desa Babakan Kecamatan Karangploso Kabupaten Malang.
\end{abstract}

Kata kunci : Sapi perah, hormon, infertilitas, sapi potong reproduksi

How to Cite :

Hendrawan, V. F., Firmawati, A., Wulansari, D., Oktanella, Y., \& Agustina, G. C. (2019) Pemberian Vitamin Sebagai Penanganan Gangguan Reproduksi Sapi Kelompok Ternak Desa Babakan, Kecamatan Karangploso, Kabupaten Malang. Jurnal Nutrisi Ternak Tropis, 2 (1) 63-69
*Corresponding author :

Viski Fitri Hendrawan

Email : viski_hendrawan88@yahoo.com

Fakultas Kedokteran Hewan Universitas Brawijaya

Malang, Jawa Timur 65151 


\begin{abstract}
Cattle is potential livestock in Indonesia. In every pregnant cow, there are three different reproduction status: normal fertility, infertile, and sterile. Infertile is a condition where cows' reproduction rate become declined caused by disorders in the reproductive organs. Infertile is temporary and can be treated through medication to restore its reproduction back to normal. However, sterile is a condition where the reproduction process is stopped and cannot be treated anymore. There are several factors which affect cows' infertility, and in most cases were caused by hormonal disorders, especially on the reproductive hormone. The cows with reproductive hormonal disorders usually indicated by the occurrence of silent heat and subestrus, as both were caused by low estrogen hormone levels. However, in delayed ovulation, anovulation, and follicular cyst, the cases were caused by the low gonadotrophin (FSH and LH) hormone levels. The hormonal disorders can occur in dairy cows with high milk production and can be caused by endometritis from abnormal birthing process, such as abortion, retention secundarium, premature, giving birth to twins, dystocia, or injury during the birthing process. The aim of this activity is to prevent the occurrence of reproduction disorders in cow while also improve its reproductive performance by detecting cows' heat on Babakan Village Farmer Group in Karangploso Sub-District, Malang Regency.
\end{abstract}

Keywords: Dairy cow, hormone, infertility, livestock reproduction

\section{PENDAHULUAN}

Secara nasional, kebutuha untuk memenuhi konsumsi susu dan daging sapi di Indonesia setiap tahun selalu meningkat, sejalan dengan bertambahnya jumlah penduduk, peningkatan pendapatan, dan kesejahteraan masyarakat serta semakin tingginya tingkat kesadaran masyarakat akan pentingnya protein hewani. Kebutuhan gizi hewani Indonesia khususnya susu dan daging sapi masih diperoleh dari tiga sumber yaitu peternakan rakyat, peternakan komersial dan impor.

Sapi merupakan ternak penghasil susu dan daging yang sangat potensial di Indonesia. Namun, ada kendala dalam usaha peternakan sapi perah, salah satunya merupakan akibat dari manejemen peternakan rakyat yang kurang baik. Selain itu, sapi perah yang berproduksi tinggi seringkali mengalami gangguan reproduksi yang kurang bagus sehingga populasinya cenderung menurun. Adanya manajemen ternak yang lebih baik meningkatkan daya tahan reproduksi sehingga menghasilkan efisiensi reproduksi tinggi diikuti produktivitas tinggi pada ternak tersebut (Choliq, 2009).Banyak faktor yang dapat menyebabkan gangguan reproduksi pada ternak sapi, yang mayoritas merupakan gangguan hormonal serta kurang nya kepedulian peternak tentang kebersihan kandang yang kadang-kadang kurang diperhatikan. Gangguan reproduksi mempengaruhi produksi hormon reproduksi yang menyebabkan estrus pada ternak menjadi terlambat (Handayani et al. 2014).

Masalah yang di timbulkan karena faktor hormonal dan kebersihan kandang sangat banyak, antara lain menimbulkan gejala seperti silent heat (birahi tenang) dan subestrus (birahi pendek) disebabkan oleh rendahnya kadar hormon estrogen. Sedangkan untuk kasus delayed ovulasi (ovulasi tertunda), anovulasi (kegagalan ovulasi) dan kista folikuler disebabkan oleh rendahnyanya kadar hormon gonadotropin (FSH dan LH). Pakan yang kekurangan nutrisi menyebabkan menurunnya fungsi kelenjar, salah satunya penurunan sekresi hormon gonadotropin (FSH dan LH) akibat dari menurunnya hipofisa anterior. Gangguan hormonal tersebut dapat terjadi pada indukan sapi berproduksi susu tinggi serta akibat adanya endometritis yang berasal dari kelahiran yang tidak normal, seperti: abortus, retensi sekundinarum, 
kelahiran prematur, kelahiran kembar, distokia, ataupun perlukaan saat melakukan pertolongan kelahiran. Pemerintah Indonesia pada tahun anggaran 2012 telah mengalokasikan dana dekonsentrasi di provinsi dan dana tugas pembantuan di kabupaten/kota untuk kegiatan pengembangan pembibitan sapi potong dalam rangka memperkuat usaha kelompok pembibitan untuk meningkatkan populasi sapi potong di Indonesia.

Maka dari itu, diperlukan pengoptimalan dalam pengembangan pembibitan ternak serta keterpaduan antara pemerintah pusat, pemerintah provinsi dan kabupaten dalam pelaksanaan bimbingan dan pengawasan terhadap kelompok peternak penerima (Departemen Pertanian Indonesia, 2012). Kegiatan pengabdian masyarakat ini pada kelompok ternak di Desa Babakan Kecamatan Karangploso Kabupaten Malang. Setiap induk ternak mempunyai tiga kemungkinan status reproduksi yaitu: berada pada kondisi kesuburan yang normal, kondisi kemajiran yang ringan atau infertil, kondisi kemajiran yang tetap atau steril. Rendahnya tingkat pendidikan masyarakat berpengaruh pada kemampuan menejemen pemeliharaan dan pembibitan hewan dan kesehatan reproduksi hewan. Oleh karena itu, civitas akademika Fakultas Kedokteran Hewan Universitas Brawijaya ingin memberikan kontribusi berupa berbagi pengetahuan kepada kelompok ternak di Desa Babakan Kecamatan Karangploso Kabupaten Malang. Khususnya masyarakat petani peternak untuk memberikan pemeriksaan kesehatan ternak kepada masyarakat petani peternak di desa tersebut.

\section{MATERI DAN METODE}

Sasaran dalam kegiatan ini adalah seluruh kelompok ternak sapi serta seluruh masyarakat di Desa Babakan Kecamatan Karangploso Kabupaten Malang. Kegiatan dimulai dari 1.) Penyuluhan tentang manajemen kesehatan ternak dan reproduksi sapi, 2.) Pembagian materi dalam bentuk hardcopy, 3.) pemeriksaan kesehatan ternak secara umum; dan 4.) pemeriksaan gangguan reproduksi. Penyuluhan dilakukan dengan memberikan wawasan dan berdiskusi tentang manajemen kesehatan ternak sapi, perawatan yang baik pada ternak, tanda-tanda estrus serta mengetahui ciri dari ternak yang mengalami gangguan reproduksi.

Pelaksanaan program kegiatan dilakukan dalam waktu 3 hari untuk desa terkait, serta adanya program evaluasi kepada masyarakat petani peternak di desa terkait untuk melihat perkembangan dari pelaksanaan program ini yang meliputi peningkatan wawasan terhadap kesehatan reproduski ternak, dan kemajuan sosial ekonomi yang dilihat dari sisi kesehatan dan perbaikan perbibitan hewan dengan cara peninjauan ke lokasi.

\section{HASIL DAN PEMBAHASAN}

Kegiatan pengabdian masyarakat ini dilaksanakan di kelompok ternak di Desa Babakan Kecamatan Karangploso Kabupaten Malang. Rendahnya tingkat pendidikan masyarakat berpengaruh pada kemampuan menejemen pemeliharaan dan pembibitan hewan dan kesehatan reproduksi hewan. Oleh karena itu, dengan diadakan nya kegiatan ini diharapkan dapat menambah wawasan dari para peternak dalam mengetahui ciri-ciri sapi yang sedang estrus maupun ciri-ciri ternak yang mengalami gangguan reproduksi, diharapkan dengan mengetahui kondisi secara dini ciri-ciri tersebut peternak dapat mencegah maupun melaporkan kepada petugas atau dokter hewan setempat untuk segera di tangani sebelum terlambat.

Cakupan kegiatan yang dilakukan antara lain sebagai upaya untuk meningkatkan kesejahteraan masyarakat petani peternak melalui pelayanan kesehatan hewan yang meliputi perawatan ternak sakit, pelayanan dan konsultasi kesehatan hewan, pemberian vitamin $\mathrm{B}$ kompleks, dan penanggulangan penyakit hewan serta pemeriksaan gangguan 
reproduksi. Pemberian obat cacing perlu dipertimbangkan diantaranya adalah harga serta jenis obat cacing apa yang tepat untuk cacing yang menginfeksi ternak tersebut, misalnya obat cacing yang efektif untuk cacing nematode belum tentu efektif untuk cacing trematoda, serta dari kondisi sapi yang memiliki ciri-ciri sapi terserang gejala cacingan sangat tergantung dari jenis cacing yang menyerang ternak sapi. Tetapi pada umumnya gejala cacingan dapat terlihat seperti badan kurus, bulu kusam dan berdiri, diare. Gejala yang diakibatkan infeksi cacing $S$. Bovis yaitu diare, hepatosplenomegali, konstipasi, meningkatnya aktivitas fagositik mononukleus, menurunnya berat badan dan kondisi tubuh ternak menjadi lemah.

Diduga bahwa hampir semua sapi yang dipelihara secara tradisional pada kondisi petani terserang penyakit cacingan. Hal tersebut didukung Ahmad, Deddy, dan Dewa (2004) tingginya penyakit cacingan pada ternak sapi disebabkan kurangnya pengetahuan dan kesadaran peternak maupun petani akan pentingnya kegiatan sanitasi dan keadaan kandang yang higienis serta sistem pemeliharaan yang dilakukan masih tradisional.

Berat ringannya akibat yang ditimbulkan olehserangan parasit cacing tergantung pada jenis cacing, jumlah cacing yang menyerang, umur sapi yang terserang dan kondisi pakan. Menurut Vercruysse et al. (2002), penggunaan antelmintik sebaiknya menggunakan obat yang mempunyai efikasi 90 persen atau lebih. Pemakaian antelmintik yang mempunyai efikasi yang rendah dapat memicu terjadinya resistensi. Adanya kemungkinan telah terjadi resistensi tersebut sangat merugikan peternak karena berarti obat yang diberikan kurang efektif lagi dalam mengendalikan penyakit sehingga produktivitas ternak tetap rendah dan menurunkan income dari peternak. Albendazole (ABZ), salah satu anggota dari kelas BZD dengan senyawa metil karbamat yang efektif melawan nematoda gastrointestinal, cacing pita, dan cacing hati sehingga obat albendazole dipilih untuk pengobatan dan pencegahan penyakit parasit pada kegiatan pengabdian masyarakat ini. Obat-obat tersebut tersedia secara luas di sebagian besar sistem pelayanan kesehatan sebagai pengobatan kuratif dari kasus kasus klinis selama bertahun-tahun.

Jumlah sapi yang memperoleh pengobatan cacing gratis pada pengmas ini sebanyak 97 ekor. Tanpa kelengkapan nutrisi yang baik dan dalam jumlah memadai maka meskipun ternak tersebut merupakan bibit unggul akan kurang dapat memperlihatkan keunggulannya. Gangguan kesehatan dan reproduksi diakibatkan dari pakan yang kurang nutrisinya. Gangguan kesehatan dan reproduksi diakibatkan dari pakan yang kurang nutrisinya. Kekurangan nutrisi pada pakan menyebabkan tidak optimalnya aktivitas ovarium, adanya gangguan hormon, dan Body Condition Score (BCS) yang rendah, kawin berulang yang disebabkan karena calving interval menjadi panjang (Prihatno, dkk. 2013).

Kelengkapan zat gizi dalam makanan ternak ruminansia akan dapat mempercepat pubertas pada kambing, estrus pertama setelah melahirkan, menjaga kebuntingan, berat anak lahir, berat anak setelah kambing serta menjaga kondisi induk saat laktasi. Mikronutrisi pada hewan yang dibutuhkan untuk metabolisme agar tercapai kesehatan yang optimal yaitu vitamin (Kurnia, Tyas, dan Sri 2015). Vitamin B merupakan jenis vitamin yang paling banyak dibutuhkan dalam tubuh kambing. Vitamin B adalah jenis vitamin yang larut dalam air dan memainkan peran penting dalam metabolisme sel. Ada 8 jenis vitamin B yaitu vitamin B1, B2, B3, B5, B6, B7, B9, dan B12. Vitamin ini sepenuhnya bisa dibentuk dalam tubuh hewan yang memamah biak seperti kambing, sehingga kemungkinan terjadinya kekurangan vitamin B1 sangat kecil. 
Tabel 1. Nama peternak dan jumlah sapi yang diberi Vitamin, B12, dan obat cacing.

\begin{tabular}{|c|c|c|c|c|c|}
\hline No. & $\begin{array}{l}\text { Nama } \\
\text { Pemilik }\end{array}$ & $\begin{array}{c}\text { Jumlah } \\
\text { ternak }\end{array}$ & $\begin{array}{l}\text { Jenis } \\
\text { ternak } \\
\text { (spesies) }\end{array}$ & $\begin{array}{c}\text { Hasil } \\
\text { pemeriksaan }\end{array}$ & Pelayanan \\
\hline 1 & Winarno & 12 ekor & $\begin{array}{c}\text { Sapi } \\
\text { Limousin }\end{array}$ & $\begin{array}{l}\text { - Tidak bunting } \\
\text { - Tidak estrus }\end{array}$ & $\begin{array}{l}\text { - Suntik Vitamin } \\
\text { - Pemberian mineral + } \\
\text { obat cacing }\end{array}$ \\
\hline 2 & Yoyon & 9 ekor & $\begin{array}{c}\text { Sapi } \\
\text { Simmental }\end{array}$ & $\begin{array}{l}\text { - Tidak bunting } \\
\text { - Estrus }\end{array}$ & $\begin{array}{l}\text { - Suntik Vitamin } \\
\text { - Pemberian mineral + } \\
\text { obat cacing }\end{array}$ \\
\hline 3 & Supungat & 7 ekor & $\begin{array}{c}\text { Sapi } \\
\text { Simmental }\end{array}$ & - Tidak bunting & $\begin{array}{l}\text { - Suntik Vitamin } \\
\text { - Pemberian mineral + } \\
\text { obat cacing }\end{array}$ \\
\hline 4 & Asnan & 6 ekor & $\begin{array}{l}\text { Sapi FH } \\
\text { Sapi } \\
\text { Simmental }\end{array}$ & $\begin{array}{l}\text { - Tidak bunting } \\
\text { - } 2 \text { ekor bunting }\end{array}$ & $\begin{array}{l}\text { - Suntik Vitamin } \\
\text { - Pemberian mineral + } \\
\text { obat cacing } \\
\text { - Pemberian calsidex }\end{array}$ \\
\hline 5 & Zainal & 14 ekor & $\begin{array}{c}\text { Sapi } \\
\text { Limousin } \\
\text { dan Sapi FH }\end{array}$ & $\begin{array}{l}\text { - } 5 \text { ekor Bunting } \\
\text { - Tidak bunting }\end{array}$ & $\begin{array}{l}\text { - Suntik Vitamin } \\
\text { - Pemberian mineral } \\
\text { - Pemberian biodin }\end{array}$ \\
\hline 6 & Satir & 6 ekor & $\begin{array}{c}\text { Sapi } \\
\text { Limousin } \\
\text { dan FH }\end{array}$ & $\begin{array}{l}\text { - Tidak bunting } \\
\text { - Estrus }\end{array}$ & $\begin{array}{l}\text { - IB straw limousin } \\
\text { - Suntik Vitamin } \\
\text { - Pemberian mineral + } \\
\text { obat cacing }\end{array}$ \\
\hline 7 & Gianto & 6 ekor & $\begin{array}{c}\text { Sapi } \\
\text { Limousin }\end{array}$ & - Tidak bunting & $\begin{array}{l}\text { - Suntik Vitamin } \\
\text { - Pemberian mineral + } \\
\text { obat cacing }\end{array}$ \\
\hline 8 & Nardi & 5 ekor & $\begin{array}{c}\text { Sapi } \\
\text { Limousin }\end{array}$ & $\begin{array}{l}\text { - Tidak bunting } \\
\text { - Mendekati } \\
\text { estrus }\end{array}$ & $\begin{array}{l}\text { - Suntik Vitamin } \\
\text { - Pemberian mineral + } \\
\text { obat cacing } \\
\text { - IB }\end{array}$ \\
\hline 9 & Supriadi & 3 ekor & $\begin{array}{c}\text { Sapi } \\
\text { Simmental }\end{array}$ & $\begin{array}{l}\text { - Tidak bunting } \\
\text { - Mendekati } \\
\text { estrus }\end{array}$ & $\begin{array}{l}\text { - Suntik Vitamin } \\
\text { - Pemberian mineral + } \\
\text { obat cacing } \\
\text { - Pemberian Biodin } \\
\text { - IB }\end{array}$ \\
\hline 10 & Janari & 1 ekor & Sapi Angus & $\begin{array}{l}\text { - Tidak bunting } \\
\text { - Tidak estrus }\end{array}$ & $\begin{array}{l}\text { - Suntik Vitamin } \\
\text { - Pemberian mineral + } \\
\text { obat cacing }\end{array}$ \\
\hline 11 & Edi & 2 ekor & $\begin{array}{c}\text { Sapi } \\
\text { Simmental }\end{array}$ & $\begin{array}{l}\text { - Tidak bunting } \\
\text { - Tidak estrus }\end{array}$ & $\begin{array}{l}\text { - Suntik Vitamin } \\
\text { - Pemberian mineral + } \\
\text { obat cacing }\end{array}$ \\
\hline 12 & Samsul & 2 ekor & $\begin{array}{l}\text { Sapi PO } \\
\text { Sapi } \\
\text { Limousin }\end{array}$ & $\begin{array}{l}\text { - Keduanya } \\
\text { tidak bunting }\end{array}$ & $\begin{array}{l}\text { - Suntik Vitamin } \\
\text { - Pemberian mineral + } \\
\text { obat cacing }\end{array}$ \\
\hline 13 & Roni & 3 ekor & Sapi FH & $\begin{array}{l}\text { - Tidak bunting } \\
\text { - Tidak estrus }\end{array}$ & $\begin{array}{l}\text { - Suntik Vitamin } \\
\text { - Pemberian mineral + } \\
\text { obat cacing }\end{array}$ \\
\hline
\end{tabular}




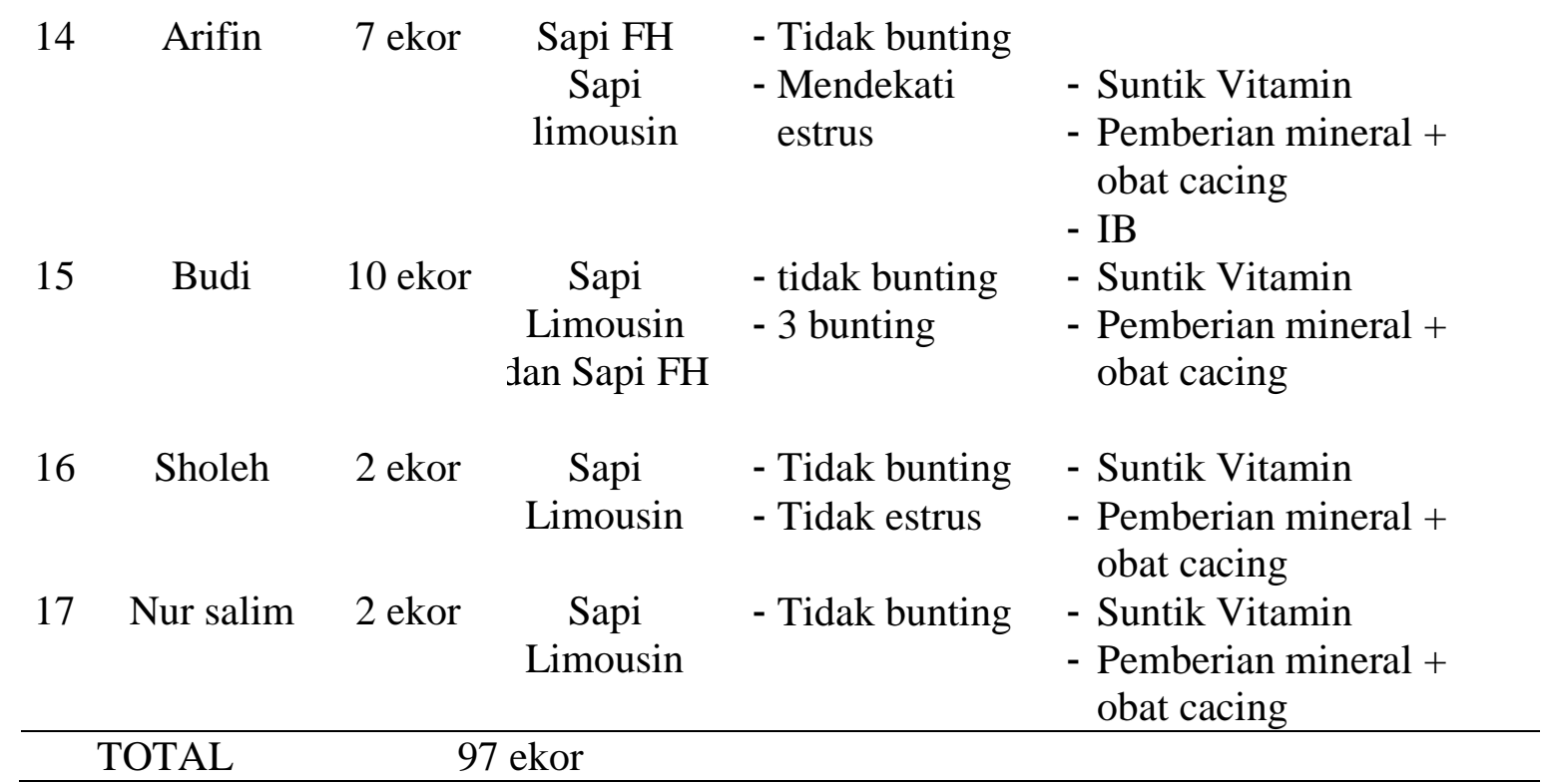

Pemberian vitamin B kompleks diharapkan dapat meningkatkan nafsu makan sehingga akan memperbaiki sistem ketahanan tubuh. Sandjaja dan Atmarita (2009) bahwa vitamin B kompleks merupakan kelompok vitamin B yang berfungsi sebagai energi bagi tubuh ternak dan memperbaiki stamina tubuh. Selain pemberian obat cacing dan vitamin ada juga penyuluhan dan pemeriksaan gangguan reproduksi seperti data Tabel 1.1 di atas. Kegiatan ini tidak hanya melakukan pengobatan dan penyuluhan tetapi juga dilakukan pemeriksaan kebuntingan dan pemberian IB gratis yang di mana para peternak juga di beri penjelasan bagaimana sapi dianggap estrus. Pada kegiatan pengabdian masyarakat yang dilakukan di Desa Babakan ini kami melihat para peternak belum mengetahui secara jelas tanda-tanda sapi birahi.

Kegiatan penyuluhan yang disampaikan pada peternak selain masalah pengobatan kami juga menitikberatkan pada tanda-tanda birahi pada sapi, agar nantinya para peternak tidak salah dalam melakukan IB. Banyak kasus yang ditemui di lapangan yang berhubungan dengan reproduksi, salah satunya dilakukan IB beberapa kali tetapi tidak jadi. Hal ini dapat di pengaruhi beberapa faktor yaitu hewan betina, pakan, peternak dan operator IB. Hal ini didukung oleh Hastuti, Sudi, dan Rini (2008) keberhasilan IB ditentukan faktor manusia, karena manusia memiliki peranan yang krusial dalam keberhasilan IB, selain itu keberhasilan IB dipengaruhi oleh faktor yang sangat dominan diantaranya sarana dan kondisi lapangan.

Hewan yang mendapatkan pelayanan pada kegiatan pengabdian masyarakat ini mayoritas adalah sapi. Jenis-jenis sapi yang mendapatkan pelayanan IB pada kegiatan pengabdian masyarakat antara lain: Sapi Limousin, Sapi Simmental, Sapi Friesian Holstein, dan Sapi Peranakan Ongole; dengan mayoritas Sapi Limousin. Sebelum mendapatkan pelayanan IB lebih lanjut, dilakukan pemeriksaan terlebih dahulu yang meliputi tanda-tanda birahi, palpasi rektal untuk melihat apakah hewan tersebut sehat pada organ reproduksi. Dari kegiatan pengabdian yang dilakukan sangat dirasakan sekali manfaatnya bagi peternak dimana pengetahuan mereka dapat bertambah dalam hal pemeliharaan dan manajemen perkawinan sapi potong yang lebih baik lagi. Sehingga diharapkan akan berdampak pada peningkatan kelahiran anak sapi dan sekaligus dapat meningkatkan populasi ternak sapi potong di masa mendatang. 


\section{KESIMPULAN}

Pelaksanaan pengmas pada Kelompok Ternak Desa Babakan, Karangploso, Malang yang meliputi pemeriksaan status reproduksi ternak, pemberian obat cacing dan vitamin, serta pemberian penyuluhan secara langsung kepada para peternak. Pemeriksaan status reproduksi dilakukan pada 10 ekor sapi dengan status reproduksi yang bervariasi diantaranya: bunting 7 ekor, tidak birahi 87 ekor, dan birahi 3 ekor. Pemberian obat cacing dan penyuntikan vitamin dilakukan pada seluruh sapi (97 ekor), namun pada sapi dengan status reproduksi bunting tidak diberikan pemberian obat cacing.

\section{DAFTAR PUSTAKA}

Ahmad, S. N., Siswansyah, D. D., \& Swastika, D. K. (2014). Kajian sistem usaha ternak sapi potong di kalimantan tengah. Jurnal Pengkajian Dan Pengembangan Teknologi Pertanian, $7(2)$, 155-170. https://doi.org/10.21082/JPPTP.V7N2.2004.P\%P

Handayani, U. F., Hartono, M., \& . S. (2014). Respon kecepatan timbulnya estrus dan lama estrus pada berbagai paritas sapi bali setelah dua kali pemberian prostaglandin $\mathrm{F} 2 \alpha(\mathrm{PGF} 2 \alpha)$. Jurnal Ilmiah Peternakan Terpadu, 2(1), 33-39. https://doi.org/10.23960/JIPT.V2I1.P\%P

Handayani, U. F., Hartono, M., \& Siswanto. (2014). Respon Kecepetan Timbbulnya Estrus Dan Lama Estrus.
Hastuti, D., Nurtini, S., \& Widiati, R. (2008). Kajian sosial ekonomi pelaksanaan inseminasi buatan sapi potong di Kabupaten Kebumen. MEDIAGRO, 4(2), 1-12

Hayati, \& Choliq. (2009). Ilmu Reproduksi Hewan. Jakarta: PT. Mutiara Sumber Widya.

Kurnia, S. D., Saraswati, T. R., \& Isdadiyanto, S. (2015). Pengaruh pemberian mikromineral ( $\mathrm{Fe}, \mathrm{Co}, \mathrm{Cu}$, $\mathrm{Zn}$ ), vitamin (a, B1, B12, C) dan jus mengkudu (morinda citrifolia 1.) terhadap konsumsi pakan, bobot lemak abdominal dan jumlah folikel ovarium yang berkembang pada puyuh (coturnix coturnix japonica 1.). Buletin Anatomi Dan Fisiologi, 23(2), 43-47

Prihatno, Agus, S., Kusumawati, A., Karja, N. W. K., \& Sumiarto, B. (2013). Prevalensi dan faktor risiko kawin berulang pada sapi perah pada tingkat peternak. Jurnal Veteriner, 14(452-461).

Sandjaja, \& Atmarita. (2009). Kamus Gizi. Jakarta: PT. Kompas Media Nusantara.

Vercruysse, J., Holdsworth, P., Letonja, T., Conder, G., Hamamoto, K., Okano, K., \& Rehbein, S. (2002). International harmonisation of anthelmintic efficacy guidelines (Part 2). Veterinary Parasitology, 103(4), 277-297 